\title{
Scott, J.W. (ed.) (2020): A Research Agenda for Border Studies (Edward Elgar, Cheltenham and Northampton, 208 pp)
}

\author{
PÉTER BALOGH
}

\begin{abstract}
Péter BALOGH: assistant professor, Department of Social and Economic Geography, Institute of Geography and Earth Sciences, ELTE Eötvös Loránd University; Pázmány Péter sétány 1/C,H-1117 Budapest, Hungary; peter.balogh@ttk.elte.hu; research fellow, CERS Institute for Regional Studies; Papnövelde u. 22., H- 7621 Pécs, Hungary; balogh.peter@krtk.hu; https://orcid.org/0000-0001-8220-3220
\end{abstract}

BALOGH Péter: adjunktus, Eötvös Loránd Tudományegyetem, Földrajz- és Földtudományi Intézet, Társadalom- és Gazdaságföldrajzi Tanszék; 1117 Budapest; Pázmány Péter sétány 1/C, peter.balogh@ttk.elte.hu; tudományos munkatárs, KRTK Regionális Kutatások Intézete; 7621 Pécs, Papnövelde u. 22.; balogh.peter@krtk.hu; https://orcid.org/0000-0001-8220-3220

It is now a truism that borders are highly complex and multifaceted features of socio-spatial life, which have accordingly been studied in multifarious ways - something also reflected by this book. Here the reader holds in her/his hands a volume edited by one of the most established border scholars of our days, including some of the most noted contributors to the field. These chapters provide an excellent selection of recent approaches, though - as James Scott rightly acknowledges - serving a full-fledged state of the art is impossible (p. 5). In a way the editor has already done the critical part of the reviewer's job by admitting that the volume is not a 'definitive research agenda but a number of research perspectives' (p. 5). Accordingly, if anyone is looking for a coherent account of 'how to go about' in the study of borders, then this edited volume can undoubtedly provide various impetuses but cannot be treated as a strictly cohesive guide or an overarching framework. It can be noted here that while Border studies has grown into a broad field, the question whether a single or dominant border theory is possible or even desirable has been debated (Paasi 2011). The cautious approach of Scott and others to authoritatively define a single border agenda is therefore understandable and realistic: we simply need to be aware of and further develop existing approaches to see which one works best in any given case, or perhaps more broadly.

Because the editor's introductory chapter considers the background and especially the state of the art more generally, it is worth discussing it at greater length here. Border studies is nowadays often - as here (p. 3) - considered to be about three decades old. This is of course true if we think of the initially westerndominated body of literature that became established in the 1990s. But briefly looking back helps us understand the shifting logics and motivations behind studying borders, which go back to at least Friedrich Ratzel. Up until World War

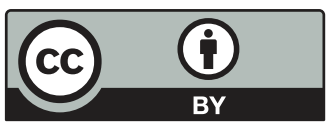


II, however, such studies typically served to legitimise various national interests, often with dire outcomes. During the Cold War, borders were relatively stable and often strictly controlled, resulting in reduced contacts across them. Relatedly, the relatively few studies of borders during this time focused on the 'correctness' of various boundary demarcations, including subnational (e.g. in electoral geography or planning, but see also Iossifova's chapter in the volume on intraurban scales). Even in the 1990s, the 'new' Border studies was revived as a counter-narrative to then emerging notions of a borderless world (Newman 2006), pointing to the continued importance of boundaries despite globalisation and the growing use of ICTs (p. 3). Yet the analysis was now more sophisticated, taking into account not just physical demarcations but also various practices of everyday life (such as public attitudes, humour etc.) that maintain borders even following the removal of physical barriers (Newman 2006), and so the focus broadened to include mental borders (van Houtum 1999). What happened around this time was that the hitherto separate fields of geographical borders and studies of social differentiation and othering - which in sociology for instance go back to at least Georg Simmel - began to inform each other (p. 9, see also Español's chapter), leading to a vivid and expanding multi- or even post-disciplinary field 'in a state of constant flux', but for which it is accordingly difficult to define any overarching research agenda (p. 3).

What, then, is current Border studies like? As the editor notes, there is now 'a strong post-national agenda' to transcend particularism and territorial anxieties (p. 6). Interestingly and importantly, this has emerged at a time when such thinking is rejected by many (national) politicians but also ordinary citizens (pp 7-8). This should be less surprising if we consider that throughout history, periods of increased flows and closure have evolved dialectically (Meyer, Geschiere 1999). As Scott and his edited volume show, recent trends towards strengthening borders have led some border scholars to question such practices. Some of this work views boundaries as instruments of power and exclusion (p. 6), emphasising the severe conditions that many people face when trying to cross them (see Casaglia's chapter). Another strand of research has focused on the sorts of transnational lives that many people are more or less voluntarily conducting. At the same time, transnationalism (Balogh 2013) and also some of the areas that the editor identifies with the post-national agenda - such as crossborder cooperation and using the border as resource (p. 6, also discussed in Sohn's contribution) - are all contingent on the presence of (national) boundaries, which remain remarkably enduring.

Most border scholars have of course realised this, but just leaving the subject there would fundamentally miss some important empirical realities. One strand of thought has been the development of the 'borders are everywhere' thesis (Rumford 2012). This is related to the trend towards 'more fluid understandings' of borders, which are 'now widely understood as part of a much larger complex of 
regimes, practices and narratives' (p. 6). Thus borders have recently been studied as assemblages, diffused 'within society and through the agency of multi-actor networks that include, among others, the state, local governments, private firms, humanitarian organizations and international organizations' (pp 6-7). Indeed, border-making goes on not just in space but also 'through political discourses and institutions, media representations, school textbooks, stereotypes' (pp 9-10) etc. But over-extending the term 'border' as a synonym of all forms of social control (O'Dowd 2010) can lead to its conceptual inflation and the loss of its analytical value: similarly to other large concepts such as power, if the border is everywhere, it is nowhere.

As more or less explicit responses to this dilemma, several approaches have recently been developed that point to more specific characteristics of borders and borderlands. Many are also presented in the book, but all cannot be dealt with in the framework of this review. A concept increasingly appropriated in the last few years is that of 'borderscapes'. These are 'multilocal socio-political arenas that emerge around border(ing) contexts and are thus diffused beyond the physical border' (p. 10). They can include practices and performances but also representations, communicative means and strategies related to borders, including cultural appropriations but also social contestations. This way, 'the borderscape is both a reflection and re-appropriation of an existing border context' (p. 11). It seems this idea can be tied to a somewhat older one, which is that the periphery is not at all marginal in terms of creating cultural etc. value (Lee 1991). Similarly, '[b]order thinking is a way of seeing the world and social reality from the vantage point of being at social, cultural and political borders, in which diversity, the coexistence of many different social worlds and the daily negotiation of border-crossing rituals, e.g. code switching, is the norm' (pp 19-20). Therefore it is not a coincidence that borderlands 'have become sources of cultural knowledge and vital forces of cultural change' (p. 20).

As a different way of approaching borders, Kurki's chapter suggests paying attention to materialised narratives. Her focus is on tangible objects, including works of art but also more everyday things, owned or prepared by people living at or crossing borders. The interesting part is how people relate to such objects in terms of their experiences of borders. These can include negative ones such as displacement, feelings of alienation, exclusion or loss (in the Hungarian context, we can think of Great Hungary souvenirs for instance); but also positive ones such as expectations, hope or resilience. What emerge are 'objectscapes' in which objects provide a view on the material landscape in people's lives, located in their homes or their pockets. Although a few such studies have appeared 10-12 years ago which the contributor may have missed (e.g. by Ruben Gielis), this approach is indeed rather novel in Border studies and may indeed grow considering the renewed interest in materiality in the social sciences. 
Last but certainly not least, Richardson's chapter turns the attention towards larger scales. He investigates what might at first sight seem like a contradiction, namely that ' $[\mathrm{d}]$ espite our world being characterized by expansive networks and connectivity, sovereignty has come to be represented in an ever-purer form' (p. 43). This however remains a 'simulated sovereignty' (p. 46), due to increasing crossborder flows and interdependence. Also because these are rather universal trends, Richardson shows this on a North American (the US), a West European (the Netherlands), and an East Central European (Hungary) case. It is argued that 'a heightened sense of ontological insecurity - i.e. a destabilization of the processes of creating and maintaining narratives of self and belonging - is providing the conditions for a reterritorialization of the border' ( $p .47)$. The border is re-scaled in the sense that not just national but also meta-regions such as Europe are bordered against various Others (pp 49-51). However, he argues that instead of restoring ontological security, this process is creating confusion and consternation for a wide range of communities' (p. 51). Border studies therefore has a renewed purpose and responsibility (p. 52).

All in all, the edited volume is to be praised if not for its radical cohesion or narrow focus, but for all the rich and thought-provoking contributions mirroring a dynamic field which Border studies currently represents.

\section{Acknowledgement}

The author participates in a project supported by the National Research, Development and Innovation Fund of Hungary (NKFI K 134903 Geopolitical processes and imaginaries in Central Europe: states, borders, integration and regional development).

\section{References}

Balogh, P. (2013): Sleeping abroad but working at home: cross-border residential mobility between transnationalism and (re)bordering. Geografiska Annaler: Series B, Human Geography, 2., 189-204. https://doi.org/10.1111/geob.12016

Lee, O.L. (1991): On the margins of the Chinese discourse: some personal thoughts on the cultural meaning of the periphery. Daedalus, 2., 207-226.

Meyer, B., Geschiere, P. (eds.) (1999): Globalization and identity: Dialectics of flow and closure. Blackwell, Oxford

Newman, D. (2006): The lines that continue to separate us: borders in our 'borderless' world. Progress in Human Geography, 2., 143-161. https://doi.org/10.1191\%2F0309132506ph599xx

O'Dowd, L. (2010): From a 'borderless world' to a 'world of borders': 'bringing history back in'. Environment and Planning D: Society and Space, 6., 1031-1050. https://doi.org/10.1068\%2Fd2009

Paasi, A. (2011): A border theory: an unattainable dream or a realistic aim for border scholars? In: Wastl-Walter, D. (ed.): The Ashgate Research Companion to Border Studies. Routledge, London and New York, 11-31. 
Rumford, C. (2012): Towards a multiperspectival study of borders. Geopolitics, 4., 887-902.

https://doi.org/10.1080/14650045.2012.660584

van Houtum, H. (1999): Internationalisation and mental borders. Tijdschrift voor Economische en Sociale Geografie, 3., 329-335. https://doi.org/10.1111/1467-9663.00074 